\title{
100. Least Energy required to ignite the Mixtures of Air and the Vapour of Ethyl Ether.
}

\author{
By Yûzaburô NagaI and Minao Furihata. \\ Department of Applied Chemistry, Faculty of Engineering, \\ Tokyo Imperial University. \\ (Comm. by K. TAwara, M.I.A., June 12, 1927.)
}

The authors measured the least condenser-discharge spark energy required to ignite the mixtures of air and the vapour of ethyl ether. The apparatus used was similar to that described by W.A. Bone and F. R. Weston, ${ }^{1)}$ except that the poles in the present research were $1 \mathrm{~mm}$. platinum wires terminating in $0.41 \mathrm{~mm}$. diameter platinum wires cut vertically to the length. The results obtained are shown in the following tables.

Table I. The least energy required to ignite the mixtures at the pressure of $760 \mathrm{~mm}$.

\begin{tabular}{|c|c|c|c|c|c|c|}
\hline \multirow{2}{*}{$\begin{array}{c}\text { Per cent } \\
\text { of ethyl } \\
\text { ether. }\end{array}$} & \multicolumn{3}{|c|}{$\begin{array}{l}\text { Minimum igniting capacity. } \\
\text { (Microfarad) }\end{array}$} & \multicolumn{3}{|c|}{$\begin{array}{c}\text { Energy of minimum igniting spark. } \\
\left(\text { Joules } \times 10^{-3}\right)\end{array}$} \\
\hline & at 100 volts. & at 140 volts. & at 200 volts. & at 100 volts. & at 140 volts. & at 200 volts. \\
\hline 2.50 & 11.00 & - & - & 55.0 & - & - \\
\hline 2.75 & - & 3.20 & 1.90 & - & 31.4 & 38.0 \\
\hline 3.00 & 6.00 & 2.20 & 0.63 & 30.0 & 21.5 & 12.6 \\
\hline 3.25 & 4.10 & 0.97 & - & 20.5 & 9.5 & - \\
\hline 3.50 & 3.00 & - & 043 & 15.0 & - & 8.6 \\
\hline 3.75 & - & 0.77 & - & - & 7.5 & - \\
\hline 3.80 & 2.20 & - & - & 11.0 & - & - \\
\hline 4.00 & - & 0.80 & - & - & 7.8 & - \\
\hline 4.25 & 2.00 & - & - & 10.0 & - & - \\
\hline 4.50 & 2.10 & - & 0.33 & 10.5 & - & 6.6 \\
\hline 4.75 & 2.15 & 0.74 & - & 10.7 & 7.3 & - \\
\hline 4.90 & 2.95 & - & - & 14.7 & - & - \\
\hline 5.00 & 3.00 & 0.74 & - & 15.0 & 7.3 & - \\
\hline 5.25 & - & 0.74 & - & - & 7.3 & - \\
\hline 5.50 & 3.00 & 1.31 & 0.40 & 15.7 & 12.8 & 8.0 \\
\hline 5.60 & 3.00 & - & - & 15.0 & - & - \\
\hline 5.75 & 3.00 & - & - & ] 5.0 & - & - \\
\hline 5.90 & 3.00 & - & - & 15.0 & - & - \\
\hline 6.00 & - & 1.42 & 0.43 & - & 13.9 & 8.6 \\
\hline 6.10 & 3.50 & - & - & 17.5 & - & - \\
\hline 6.25 & 4.15 & - & - & 20.7 & - & - \\
\hline 650 & 6.00 & 2.19 & - & 30.0 & 21.5 & - \\
\hline 6.60 & 9.10 & - & 1.40 & 45.5 & - & 28.0 \\
\hline 6.65 & - & 3.00 & - & - & 29.4 & - \\
\hline
\end{tabular}

1) W. A. Bone and F. R. Weston, Proc. Roy. Soc., London, A, 1 10, 615, 1926. 


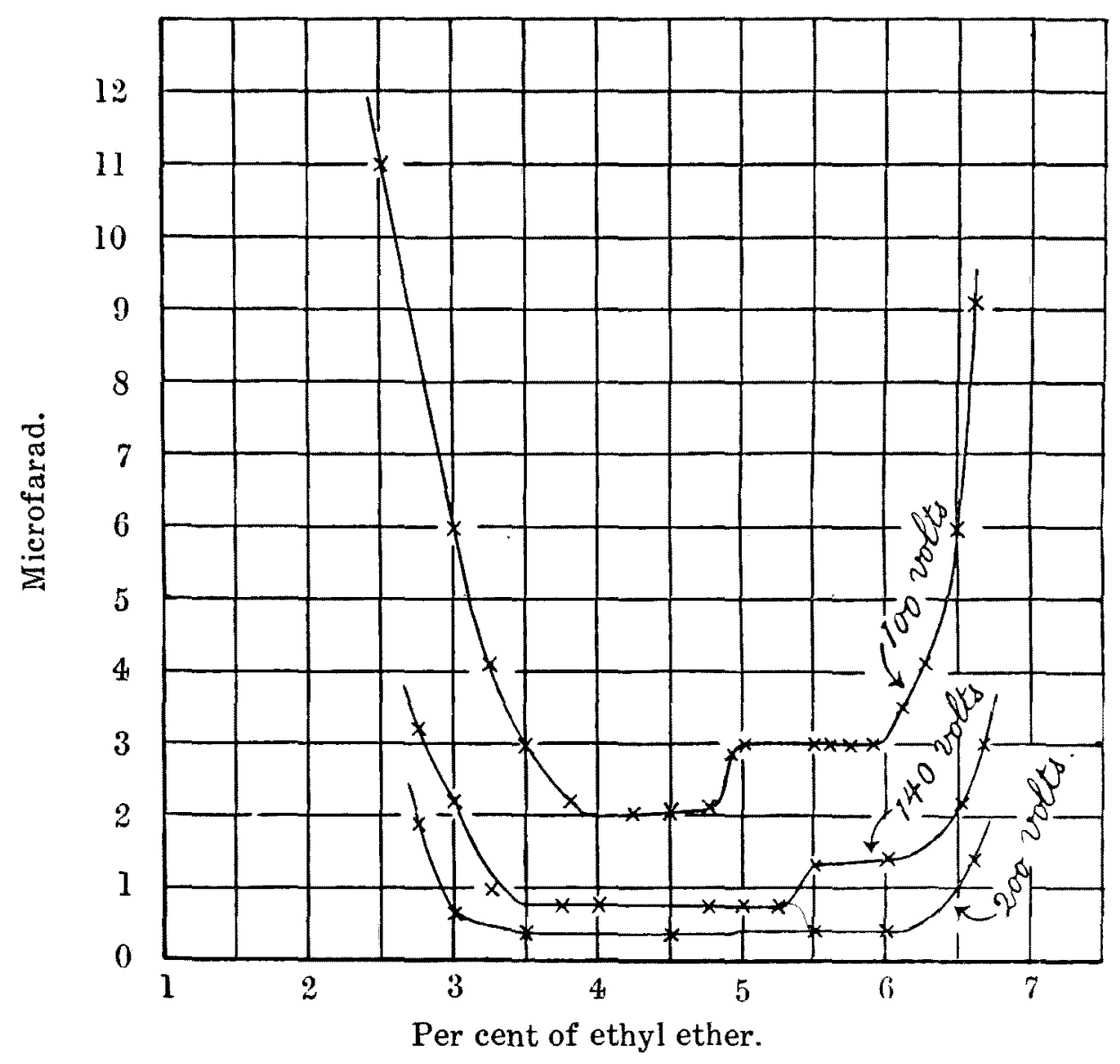

Fig. I.

These results are shown graphically in Fig. I, where it can be seen that, when the condensers are charged up to 100 volts, the least energy for ignition decreases rapidly, according as the concentration of ethyl ether in the mixture is increased from $2.5 \%$ to $3.9 \%$, but, for the range from $3.9 \%$ to $4.7 \%$, it remains constant, forming " the first horizontal stage" in the energy curve. At the concentration of $4.8 \%$ the least energy for ignition increases suddenly and it again remains constant for the range from $5.0 \%$ to $5.9 \%$, forming "the second horizontal stage." It will be noteworthy that the mixture corresponding to the minimum point of the least energy curve is not one having the composition of complete combustion (3.23\% of ethyl ether), but one much more richer in ethyl ether. When the voltage of the condensers is raised, the concentration range of the first horizontal stage is extended on both sides, resulting in the narrowing of the range of the second horizontal stage, until finally the latter stage vanishes when the condensers are charged up to 200 volts.

Table I shows also that the smaller energy is required for ignition when the condensers are charged up to the higher voltage. This will 
be due to the longer spark gap caused by the higher voltage of the condensers, the longer spark gap resulting in the smaller cooling effect of the poles.

Table II. The least energy required to ignite the mixtures at the pressure of $500 \mathrm{~mm}$.

\begin{tabular}{c|c}
\hline Per cent of ethyl ether. & \multicolumn{2}{c}{$\begin{array}{c}\text { Minimum igniting capacity } \\
\text { at 100 volts. (Microfarad). }\end{array}$} \\
\cline { 1 - 2 } 3.50 & 4.25 \\
4.00 & 3.20 \\
4.59 & 3.20 \\
4.75 & 3.15 \\
5.00 & 3.80 \\
5.50 & 3.70 \\
5.75 & 3.85 \\
6.25 & 5.15 \\
\hline
\end{tabular}

A comparison of 'Table I and II shows that, when the pressure is reduced, the least energy for ignition is increased, without changing the concentration ranges of the first and the second horizontal stages and the concentration corresponding to the sudden change of the least energy, which is $4.8 \%$ for the both pressures of $760 \mathrm{~mm}$. and $500 \mathrm{~mm}$. Therefore the value for the concentration corresponding to the sudden change of the least energy is not a function of pressure, but is a function of voltage of the condensers, as shown above. 